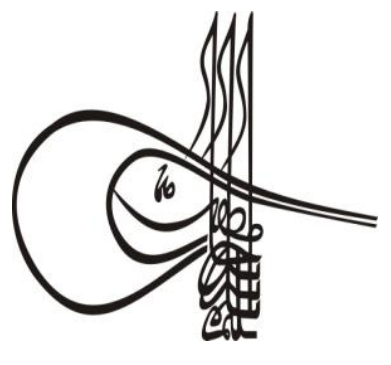

Received/Geliș: 08.11.2019

\section{Turkísh Gtudies}

Volume 14 Issue 7, 2019, p. 3799-3817

DOI: 10.29228/TurkishStudies.39666

ISSN: $1308-2140$

Skopje/MACEDONIA-Ankara/TURKEY

ResearchArticle / Araștırma Makalesi

Article Info/Makale Bilgisi

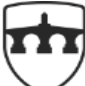

INTERNATIONAL

BALKAN

UNIVERSITY

EXCELLENCE FOR THE FUTURE IBU.EDU.MK

or Report Dates/Rapor Tarihleri: Referee 1 (14.12.2019)-Referee 2 (16.12.2019)- Referee 3 (19.12.2019)

This article was checked by iThenticate.

\title{
DİJİTAL DÖNÜŞÜM VE YAZILI BASIN ÜZERİNDEKİ ETKİLERİ
}

\author{
Ender Emre KANAAT* -Ceyda ILGAZ BÜYÜKBAYKAL** \\ Güven BÜYÜKBAYKAL $L^{* * *}$
}

\begin{abstract}
öz
Teknolojik gelişmelerdeki hızlı değişim ve paralelinde dijitalleşen tüketicilerle birlikte ekonomik, politik ve sosyal hayata yansımalar son yıllarda medya sektörünü, özellikle yazılı basını, oldukça derinden etkilemektedir.

Gerek kültürel zenginliklerimizin geleceğe taşınması gerekse basının ülke içerisinde denetim faaliyetlerini sürdürerek kamu görevini yerine getirmesi ancak finansal ve operasyonel açıdan sağlıklı işleyen bir yapının var olması ile mümkündür. Buna karşın yazılı basın perspektifinden değişimin getirdiği yeni dönemde geleneksel gazetecilik faaliyetlerini sürdürmek ticari olarak çok olası gözükmemektedir. Habercilik ihtiyacı ve bu ihtiyacı karşılamaya yönelik faaliyetler gelecekte de var olmaya devam edecektir, buna karşın içeriğin bireyler ile buluşturulmasında yeni dönemin imkanlarını ve tercihlerini göz önünde bulundurarak kendilerini adapte edebilen yazılı basin temsilcileri yaşamlarını sürdürebilecektir.

Teknolojik gelişmeler tüm sektörlerdeki işletmelere yeni kabiliyetler ve yeni değer yaratma firsatları sunmaktadır. Bu sebeple sektör temsilcilerinin hayatımıza yeni giren imkanları anlamaları, özümsemeleri ve iş süreçlerine yansıtarak yeni değerleri pazara sunmaları gerekmektedir. Bu doğrultuda ilerleyen işletmelerin geleceğe güçlü adımlar ile ilerleyecekler muhakkaktır; buna karşın değişimi kaçıran veya çeşitli nedenlerle değişime direnen işletmelerin ise büyük risk altında oldukları ve orta vadede yok olmaları kaçınılmazdır.
\end{abstract}

Dr. Bahçeşehir Üniversitesi, Sosyal Bilimler Enstitüsü, E-posta:kanaaten@gmail.com

Doç. Dr. İ.Ü.İletişim Fakültesi-Gazetecilik Bölümü, E-posta: ceydailgaz@ hotmail.com

Prof. Dr. İ.Ü.İletişim Fakültesi-Gazetecilik Bölümü, E-posta: gbuyukbaykal@ hotmail.com 
$\mathrm{Bu}$ çalışmada yazılı basın alanındaki teknolojik değişim ve gelissmelerin yazılı basını, diğer bir deyiş ile geleneksel gazeteciliği, ne şekilde etkilediği aktarılarak, bu alandaki dönüşüm irdelenecektir. Sürdürülebilirlik olgusunun tanımı yapılarak, yazılı basın perspektifinden bakıldığında mevcut sektörü etkileyen faktörler açıklanacak ve sektörün sürdürülebilirliği açısından taşıdıkları önem örneklerle irdelenecektir. Bu çalışmada ayrıca medya sektöründeki teknolojik gelişmelerin tüketici tercihlerini etkileyip etkilemediğinin, haber endüstrisindeki yeni ticari modellerin medya kurulusslarının finansal yapısına olumlu yönde yansıyıp yansımayacağının, küresel ekonomideki yavaşlamanın yazılı basını etkileyip etkilemeyeceğinin ortaya konulması amaçlanmaktadır. Çalışmanın yöntemi olarak yerli ve yabancı literatür taramasına başvurulacaktır. Ayrıca son güncel veriler, tablo ve grafiklerle yansitilacaktır.

Anahtar Kelimeler: Dijital dönüşüm, Yazılı basın, Yeni medya, Sürdürülebilirlik

\section{DIGITAL TRANSFORMATION AND ITS EFFECTS ON PRINT MEDIA}

The rapid change in technological development sand the digitalized consumers in paralell reflections on economic, political and social life affects the press quite deeply. A healthy functioning structure is only possible when moving cultural richest other future and controlling the press within the country to fulfill its public duty by continuing its activities financially and operationally.

However, the printed press in the newer a brought by change from the perspective of traditional journalism activities did not seem commercially possible. The need for journalism will continue to exist in the future but however, considering the possibilities and preferences of the newer a there presentatives of the printed press who can adapt themselves may continue. Technological developments create new capabilities and new value for businesses in all sectors offers opportunities.

For this reason, the new opportunities of the sector representatives in our lives understanding, assimilating and reflecting on business processes and introducing new values to the market is required. In this direction, progressing enterprises will move forward with strongsteps. It is certain; on the other hand, they miss the change orresist it forvarious reasons. It is inevitable that enterprises are at great risk and disappear in the mediumterm.

In this study, the technological changes and developments in the field of print media affect the print media and the transformation in this field will be discussed. From the perspective of written press the factors affecting the current sector will be explained and examined. In this study, it is also aimed to determine whether technological developments in the media sector affect consumer preferences, whether new commercial models in the news industry will be positively reflected in 
the financial structure of media organizations, and whether the slowdown in the global economy will affect the press. As a method of study, native and foreign literature review will be applied. In addition, the latest updated data, tables and graphs will be reflected.

\section{STRUCTURED ABSTRACT}

Digital transformation changes the product and service production processes of companies, increases their efficiency and efficiency, and enables them to create new values with innovation. However, it is clear that structural reforms need to be implemented in order to take advantage of the opportunities provided by digital transformation because the results achieved so far have been limited and have not yet achieved the expected momentum for economic growth.

It is the duty of governments to formulate policies and provide support to ensure the effective implementation of digital transformation. On the other hand, it is the rapid implementation of the necessary strategies for understanding the technologies and applying them to the production processes. While this process is known to require time and effort, the reforms needed to be worked on; increasing the competence of the labor force, providing access to the investment funds needed by the companies for digital transformation, supporting Research and Development ( $R \& D$ ) activities and introducing legal arrangements parallel to the needs of the new era.

It is known that due to global economic development and risks, print media is also adversely affected due to increasing costs and decreasing income. The main raw material inputs of print media, paper and ink expenses have increased considerably in the recent period. Making new investments in the printing process and maintaining the machine park is very challenging due to high financial costs. The print media industry, where labor-intensive operations are high, also has difficulty in meeting the rising costs of personnel and distribution cost items. As stated in the OECD report, digital transformation processes should be taken into consideration firstly against the risks in the global economy in terms of print media; It is of great importance to manage the cost risks on the commercial print media industry by increasing efficiency and productivity. Global Economic Conditions, which is one of the important parameters of the change, brings new challenges and issues to the agenda in terms of the print media and both public and corporate administrations are obliged to work together on sustainable economic growth that is beneficial for everyone.

In the new era, readers prefer to access newspaper content via digital channels regardless of location, time and platform. While the medium and the content, which we can call paper as a short time ago, are now being purchased together, the investments are made in electronic access devices and individuals reach the content through the new channels because of the developing technologies and the prefences of individuals change in this direction.

As the news became available on the internet, changes in the structure of traditional journalism have occurred. Digital broadcasting 
has spread rapidly around the world. The Internet has brought about transformations in the journalism profession. The Internet has brought about transformations in the journalism profession. There is quick access to internet journalism. The superiority achieved in the race against time is very important in journalism. It is much cheaper and faster than online newspaper. It also saves time and money spent on distribution. In other words, it is more cost-effective than other mass media. The publication archive is easy to access. The accessibility of internet journalism from a single center to be provided through a global circulation will bring more readers. Therefore, easy and fast access to information is the most important reason for the internet. At the same time, thanks to the internet, people now choose their own news and create their own newspapers. Nowadays, thanks to the rapidly developing technology, we are able to create a newspaper of our own, which consists of the kind of news we are interested in.

As a result of the rapid developments in the communication and informatics sector, the press has been caught unprepared in the transformation process. The new capabilities that accommodate different opportunities stand as a development area for the print media, especially on the local side that do not have sufficient knowledge, experience and financial resources.

Throughout the process, the print media has to advance to the future in new business models, new channels, new formats and new organizational structures by internalizing new technologies and reflecting them to their operational processes. While the need for Digital Transformation is a challenging and long journey, it will be the right approach for the press representatives to perceive the process as a threat and not as a threat to the future. Ensuring that the print media sector is ready for the new period in order to adapt to the conditions of the age is of great importance for the continuity of journalistic activities.

Keywords: Digital transformation, Printmedia, New media, Sustainability

\section{Giriş}

"Kitle iletişim araçları bir toplumun sadece haber alma ve eğlenme işlevini yerine getirmezler, aynı zamanda toplumun kültürel ortamının, demokratikleşme düzeyinin, toplumsal tepki ve rıza üretiminin hem aynası hem de etkileyenidirler. Bu denli önemli bir işleve sahip kitle iletişim araçları her ne kadar tecimsel şartlarda çalışsalar da kamusal dışsallıklarından ötürü diğer sektörlerden farklıdır... Toplumsal değişim süreçleri içinde medya sektörü gerek üretim gerekse işleyiş bakımından dönüşümler yaşamıştır. Bu dönüşümler bazen toplumların şekillenmesinde rol oynamış, bazense toplumsal dinamikler medya sektörünü şekillendirmiştir." (Kadıoğlu, 2018:100101)

"Gazetelerin ortaya çıkışı ve gelişmesi, insanlığın kültürel gelişmesine paralel bir çizgi izlemiştir. Gelişme, ihtiyaçlar ve zorunluluklarla aşama kaydetmiş̧ir. Bilgilerin sözle aktarıldığ sözlü kültür dönemini, yazının bulunması ile yazılı dönem izlemiş, yazının matbaada basılarak çoğaltılması ile basılı dönem başlamış, çeşitli teknolojik gelişmelerin birbirini izlemesi ile de elektrik-elektronik dönemine geçilmiştir." (Mora, 2002:118)

"Yazılı basın, öteki kitle iletişim araçları gibi, bireyin kişisel ve toplumsal ilişki ve etkileşimlerine katkıda bulunduğundan, bireyin toplumsallaşmasında önemli araçların başlıcasıdır.

\section{Turkish Studies}

Volume 14 Issue 7, 2019 
Bilgi en önemli toplumsal ürün, haber de en önemli gereksinimlerden biridir. Gazetecilik ise bir yönüyle bu iki toplumsal öğeyle ilintili olduğu için kamu görevi sayılmaktadır.” (Önür, 1998: 37)

Gazeteci, dünyanın farklı köşelerindeki ve kendi ülkesindeki olayları takip ederek, toplumsal değişimlerin ve gelişmelerin farkında olmalı ve buna bağlı olarak mesleki anlamda sürekli kendisini geliştirmelidir. Gazeteci aldığı eğitimin yanı sıra kültürel anlamda da birikim sahibi olmalı, iletişim teknolojileri donanımlı araçları kullanabilmeli ve belli bir alanda da uzmanlaşmalıdır.

"Kitle iletişim araçlarına sahip olan çevrelerin, özellikle ekonomik anlamdaki gücü, bu alanda faaliyet göstermeyen çevrelerce de artık kabul edilmiş durumdadır. Özellikle devlet yönetiminde görev yapan siyasal seçkinler ile onların hemen yanı başında yer alarak, siyasal anlamda gerçekleştirilen her tür uygulamaya müdahale etmekte olan ekonomik mülkiyet sahipleri için medya, kendi güçlerini ve ayrıcalıklı konumlarını sürdürmede kullanılabilecek önemli bir örgütlülük olarak görülmeye başlamıştır... Medyanın bu denli güçlü bir konuma gelmesinin temel nedeni ise hizmet üretimi aracıllğgyla sermaye birikimi yaratılmasındandır.

Günümüzde asıl etkinlik alanı ne olursa olsun hiçbir işletme yalnızca kendi alanıyla yetinmemekte ve diğer alanlara, daha karlı, daha çekici ya da toplumsal imaj yaratıcı daha saygın alanlara girmekten kaçınmamaktadır. Kapitalist pazar koşullarında temel amaç güç elde etmek ve gücü elinde tutmak olduğuna göre, güç alanı nerede ya da nerelerde yoğunlaşmaktaysa işletmeler de oralara doğru etkinlik alanlarını genişletme çabası içine girmektedirler. Bugün kapitalist pazarda öylesine çok yönlü bir koşuşturma, iç içe geçme ve güçlü bir büyüme hırsı vardır ki; ilkeler, kurallar, mesleki sorumluluklar vb. birçok şey birbirine karışmış durumdadır. Bu nedenle kapitalist pazarın bu karmaşası içinde yer alan basın işletmelerinin işleyişleri ve işlevleri konusunda tanımlamalar yapmak ve birtakım kategorileştirmelere gitmek gün geçtikçe daha da güçleşmektedir." (Güngör\&Tellan, 2017: 456,467)

Teknolojik gelişmelerdeki hızlı değişim ve paralelinde dijitalleşen tüketicilerle birlikte ekonomik, politik ve sosyal hayata yansımalar son yıllarda medya sektörünü, özellikle yazılı basını, oldukça derinden etkilemektedir. Gerek kültürel zenginliklerimizin geleceğe taşınması gerekse basının ülke içerisinde denetim faaliyetlerini sürdürerek demokrasiye katkıda bulunması ancak finansal ve operasyonel açıdan sağlıklı işleyen bir medya yapısının var olması ile mümkündür. Buna karşın yazılı basın perspektifinden değişimin getirdiği yeni dönemde geleneksel gazetecilik faaliyetlerini sürdürmek ticari olarak çok mümkün gözükmemektedir.

Sürdürülebilirlik, gelecekte var olmayı planladığımız durumdan bugüne gelerek faaliyetlerimizi gelecek perspektifinden düzenlemeyi içermektedir. Daimi olma yeteneğini koruyabilmek için üretkenliğin devamının sağlanması gerekmektedir. Kurumsal sürdürülebilirlik ise ticari işletmelerin gelecekte de var olmak üzere devamlılığını ifade etmektedir. İşletmelerin operasyonları esnasında paydaşlarıyla girdikleri etkileşimin işletmeye yansımalarının incelenmesidir. (Yangil 2015: 356-376)

Geleceği planlayabilmek ve sektörün sürdürülebilirliğini sağlamak açısından dört faktörü incelemek ve yazılı basına yansımalarını tartışmak oldukça önemlidir.

i) Değişen Tüketici Tercihleri

ii) Medya Sektöründeki Teknolojik Gelişmeler

iii) Habercilik Endüstrisinde Yeni Ticari Modeller

iv) Küresel Ekonomide Yavaşlama ve Yazılı Basına Finansal Yansıması

Gazetecilik faaliyetleri temelinde haber verme - haberdar olma ekseninde okur ve gazete arasındaki ilişkiyi ifade etmektedir. Geçmişte olduğu gibi gelecekte de bu ihtiyacın var olacağı 
aşikardır; buna karşın gazetecilik faaliyetlerinin gelecekte sağlıklı şekilde var olabilmesi ve sürdürülebilirliği açısından diğer sektörlerde olduğu gibi dijital dönüşüm sürecinden geçmesi kaçınılmazdır.

\section{Değişen Tüketici Tercihleri}

"İnsanlık tarihi boyunca ortaya çıkan her yeni teknoloji, beraberinde insanlara habere ve enformasyona ulaşmak için yeni olanaklar sunarken, habere ve enformasyona ulaşma alışkanlıklarının da doğal olarak değişmesine yol açmıştır. Davul sesleriyle, ıslık diliyle, duman işaretleri ve güvercinlerin taşıdığı mesajlarla başlayan, atlı posta servisiyle devam eden iletişim ve haberleşme süreçleri, yeni teknolojinin sunduğu olanaklarla gelişmiştir. Zaman içinde telgraf, radyo, televizyon, internet ve mobil teknolojilerin hayatımıza girmesi, bugün insanları çoklu ortamda, farklı iletişim araçlarıyla haberleşme noktasına getirmiştir. Doğal olarak gazeteler ve gazetecilik de bu değişimden etkilenmişlerdir. Ancak bu gelişmeleri onların 'yok olacağı' şeklinde yorumlamak doğru bir yaklaşım olmayacaktır. Haberi, kağıt üzerine mürekkeple basılmış bir araç olarak geniş kitlelere ulaştıran bu araçlar ve o aracı hazırlayan gazeteciler, kendilerini yeni ortamlara hazırlamaya başlamışlardır. Kendilerini yeni araçlara dönüştürmekte, içeriklerini zenginleştirmekte ve erişim alanlarını tüm dünyayı saran iletişim ağlarıyla genişletmektedirler. Kullanıcı da, dünya görüşüne, yaşam tarzına, alışkanlıklarına, günlük rutinlerine bağlı olarak, hangi araca, hangi yöntemle ulaşacağına kendi karar vermektedir...Online enformasyon akışı, yaşadığımız çağın gereksinimlerini karşılamak üzere doğmuş ve gelişmiştir. Gazeteleri online olarak bir ekrandan okumak, okura daha önceden kazandığı okuma alışkanlığını elbette sunmamaktadır. Ancak zamanla, özellikle gazeteyi kağıttan değil de, bir ekrandan okumaya alışarak büyüyen yeni nesillerle birlikte, kullanıcı alışkanlıklarının da önemli ölçüde değişmesi beklenebilir. İpod'un müzik endüstrisi için getirdiklerini, şimdi mobil cihazlar medya endüstrisi için getirmektedir.” (Özçağlayan, 2008: 154-155)

"Online haberleşme olgusunun yaygınlaşmasında en önemli sebep, şüphesiz internet kullanımının yaygınlaşmasıdır. İletişim ve ulaşım teknolojilerindeki gelişmeler, kitlesel iletişim olanaklarını direkt etkilemiş, online gazeteciliğe olan ilgiyi artırmıştır. Kullanıcılar bu yeni iletişim alanının onlara sunduğu teknolojik olanaklardan çok etkilenmiş, pasif durumda oldukları haber alma sürecinin, online gazetecilik formlarıyla süreç içinde aktif hale geldiğini deneyimledikçe, basılı yayınlara olan ilgileri azalmıştır." (Cansabuncu, 2013: 90)

Teknolojik kabiliyetlerin gelişimi ve teknolojiye erişimin ucuzlaması ile birlikte günlük hayatta teknolojinin kullanımı artmış ve bireyler tarafında da işletmelere benzer bir dijital dönüşüm süreci başlamıştır. Geleneksel bireyler dijital teknolojileri hayatlarının merkezine yerleştirmişler ve tercihlerini bu doğrultuda şekillendirmeye başlamışlardır.

Kadir Has Üniversitesi tarafindan her yıl düzenli olarak gerçekleştirilen Türkiye SosyalSiyasal Eğilimler 2019 Araştırması'nın içerisinde yer alan sorulardan bir tanesi okuyucuların gazeteleri hangi kanaldan okumayı tercih ettikleri üzerinedir (Figür1). Gazeteleri sadece internet üzerinden okumayı tercih edenlerin oranı \%39,6 ile gazeteyi yalnızca basılı kağıt üzerinden okumayı tercih edenlerin yaklaşık \%17,9 üzerindedir. Gazete içeriğine her iki kanaldan ulaşanların oranları karşılaştırıldığında ortaya çıkan sonuç yine dijital kanalların tercih edildiğini göstermektedir. Araştırma sonuçları ortaya koymaktadır ki yıllar içerisinde İnternet üzerinden gazeteyi okumayı tercih edenlerin oranı düzenli şekilde artmaktadır. 
Figür1: Gazeteyi Basılı ya da İnternetten okuma

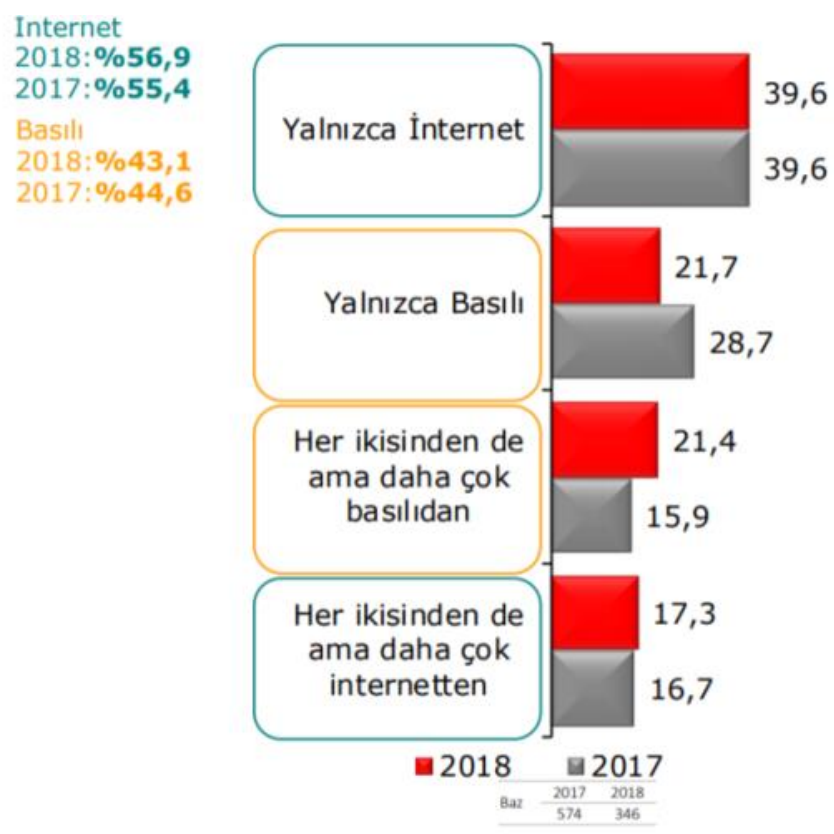

Kaynak:Kadir Has Üniversitesi Türkiye Sosyal-Siyasal Eğilimler Araştırmas1 - 2019

Yeni dönemde okurlar gazete içeriğine mekan, zaman ve platform bağımsız olarak dijital kanallar üzerinden ulaşmayı tercih etmektedirler. Kısa bir süre öncesinde kağıt olarak isimlendirebileceğimiz mecra ve içerik birlikte satın alınırken artık gelişen teknolojilerin imkan vermesi ve bireylerin tercihlerinin bu yönde değișmesi nedeni ile elektronik erișim cihazlarına yatırım yapılmakta ve bireyler sahip oldukları yeni mecralar (elektronik platformlara) üzerinden içeriğe ulaşmaktadırlar.

İçeriğe yeni erişim tercihinin sonucu olarak geleneksel kanallarda içerik tüketimi hızla azalmakta, talep hızla düşmekte ve ekonomik faaliyetler daralmaktadır. Bu sebeple ticari açıdan geleneksel kanallar üzerinden yayın faaliyetlerine devam etmek ticari işletme olan yazılı basın temsilcilerini zorlamaktadır.

Tüketiciler içerisinde mutlaka azalarak da olsa yazılı basını tercih edenler olacaktır ve muhtemelen de sonsuza kadar olmaya devam edecektir. Buna karşın mevcut ticari koşullarda düşük talebe geleneksel kanallardan içeriği sağlamak (arz etmek) sektör oyuncuları açısından ticari olarak anlamını yitirmektedir. Bahsetmiş olduğumuz bütün koşullar yazılı basının orta vadede sona yaklaştığını göstermektedir. Önemle vurgulanması gereken husus ise geleneksel gazetelere olan talebin kısıtlı da olsa mevcut olmasına karşın yazılı basının ticari nedenlerle sürdürülebilirliğinin kalmadığıdır.

Türkiye'de Günlük Yerel - Bölgesel ve Ulusal Gazete Tirajları rakamları Türkiye İstatistik Kurumu (TÜİK) tarafından açıklanmaktadır. Rakamlar incelendiğinde yıllar içerisinde değişen tüketici tercihlerinin tirajlara olumsuz yansıması açıkça görülmektedir. 2005 ve 2018 yılları arasında paylaşılan rakamlar özellikle 2013 yılından itibaren yazılı basının tirajların hızla düştügünü göstermektedir. 
Figür 2: Türkiye'de Günlük Yerel-Bölgesel ve Ulusal Gazete Tirajları

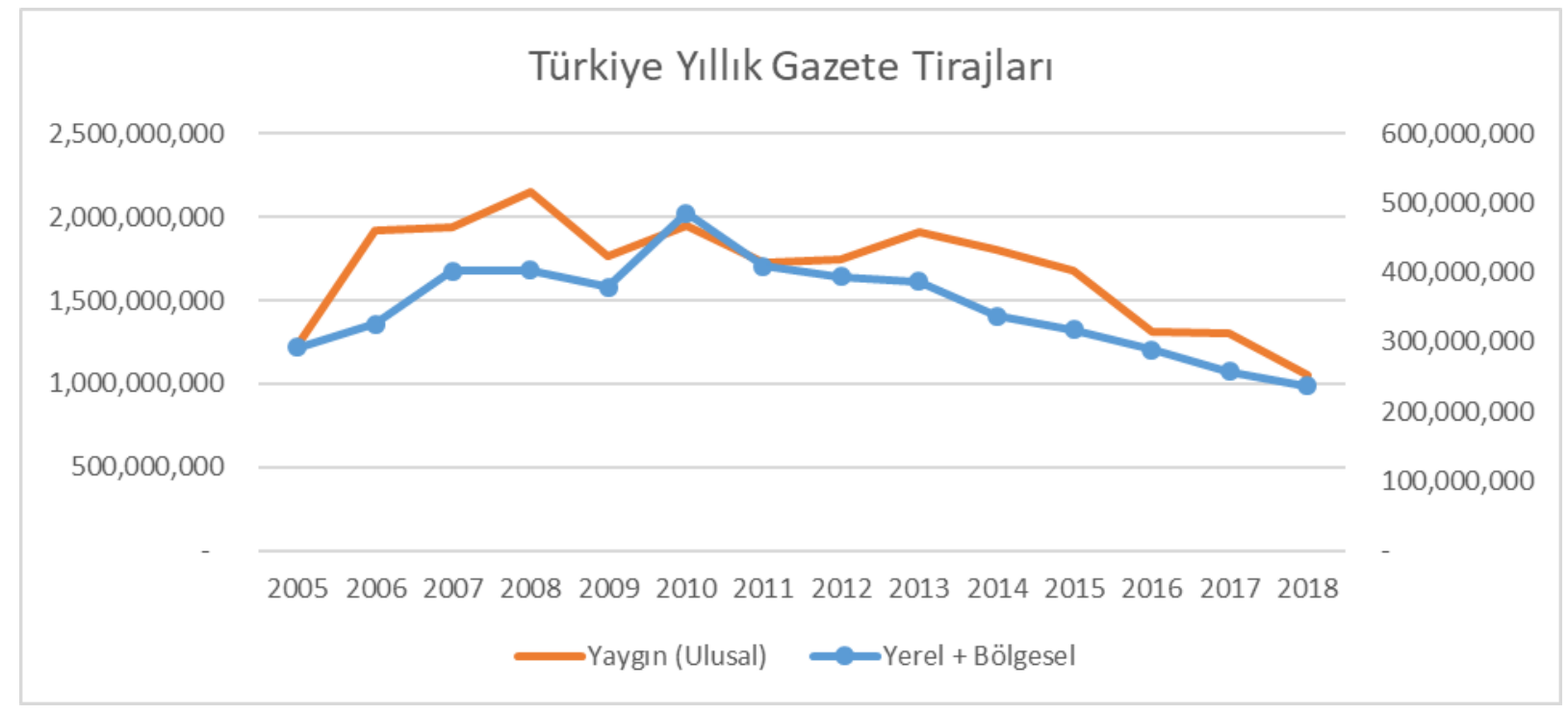

Kaynak: TÜİK Veri Derlemesi

\section{Medya Sektöründeki Teknolojik Gelişmeler}

Teknolojik gelişmeler, insanların iletişim araçlarından klasik beklentilerini değiştirmiştir. Dijital teknolojiler ile şekillenen yeni iletişim ortamı enformasyonu üretme, işleme ve yayma kapasitesine hız katmıştır.

"Dijital teknolojinin kitle iletişim araçlarına sağladığı yüksek hız, çok boyutluluk ve çeşitlilik kaçınılmaz olarak nitelik, içerik, amaç ve işlev yönünden iletişimi etkilemektedir. Kitle iletişim araçlarının bireyle ve toplumsal bilinç üzerinde yarattı̆̆ etki gücü, enformasyon devrimi ve çağı gibi kuramların ortaya çıkmasına neden olmuştur." (Mengü, 2003:42)

Geleneksel basılı medya ve televizyonlarda olduğu gibi çok büyük yatırımlara gereksinim duyulmadan, üstelik hem basılı medya, hem de televizyonların işlevlerini de içeren teknolojik özelliğiyle dünya basın tarihinde bir devrim gerçekleşmiştir. Kitlesel internet iletişimi, ilk başlarda geleneksel medyada sunulan enformasyonun yayılmasına olanak sağlayan bir işlev üstlenmiştir. Ancak sonradan bu yetmemiş, bizzat özgün içerik üretilen bir iletişim ortamına dönüşmüştür. Sosyal paylaşım sitelerinin oluşturduğu sosyal medyanın ortaya çıkışı ve yaygınlaşmaya başlamasıyla birlikte de dünyanın en büyük, en önemli kitlesel iletişim platformuna dönüşmüştür. Bir süre gelişmeleri uzaktan izleyerek kayıtsız kalan geleneksel basın, sonradan bu teknolojik devrime duyarsız kalamayacağını anlamış ve bu değişim/gelişim sürecine katılmıştır. (http://www.socialmediatr.com/13.12.2016)

Dijital devrim, içerikleri bedava okumaya alışsk ve bunu talep eden bir okuyucu türü yaratmıştır. Bunları okumak için para ödemeye ikna etmek imkansız gibi gözüküyordu. Bu durumu New York TimesveWall Street Journal gazeteleri günümüzde başarılı bir biçimde sürdürmektedir. Her iki gazete de çok farklı ve kaliteli içerik sunarak siteleri için başarılı bir iş modelini oluşturup çalıştırmayı başarmışlardır. New York Times geleneksel medyanın hakimi olmasına rağmen kaçınılmaz değişimi hızla kabul ederek, kendisini yenilemiş ve büyük değişime kısa sürede ayak uydurmuştur. Geleneksel medyanın en büyük hatası, gücü artan internet medyasına karşı kurdukları sitelerine kağıt baskı gazetenin içeriğini aynen aktarmak olmuştur. Ancak okurun beklentisi farklı ve orijinal içeriktir. New York Times gazetesi yeni medyaya özgü orijinal içeriği sayesinde başarılı olmuştur. 
İnternetin yaygınlaşması, geleneksel karakterdeki kitle iletişim araçlarının yapılarının yanı sıra iletişim yöntemlerini de değiştirmelerini zorunlu kılmıştır. Gazeteler varoluş nedenleri olan haber verme işlevlerini geleneksel yapısının yanı sıra internet ortamında sürdürmeye çalışmış, bunu da en etkin ve teknolojinin sunduğu yeni olanakları kullanarak yapmak durumunda kalmıştır. Bu yeni habercilik düzeninde haber, toplumun bilgi ve ilgisini geliştirecek, gerçekliğin kurgusal olarak yayınlanacağı medya organizasyonunun yapısına, teknolojisine ve ideolojisine göre yeniden kurgulanmakta ve sunulmaktadır. (Çakır, 2007: 138)

20. yüzyılda "Dijital Dönüşüm” kavramı gerek bireyleri gerekse kurumları derinden etkilemektedir. Cihazlarda ve bilgisayarlarda artan işletim hızı ve donanım kabiliyetleri, internet teknolojilerindeki yüksek hız ve kapasite artışı ve ayrıca teknolojiye erişim maliyetlerindeki düşüş bireylerin günlük hayatlarında teknolojiyi rahatlıkla kullanmalarını sağlamış ve yaşam şekillerini değiştirmiştir. İçinde bulunduğumuz dönemin bireyleri dijital tüketicilere dönüşmüş̧ ve kendi yaşam tarzlarına uygun olarak yeni dijital ürün ve servisleri dijital kanallardan tüketmeyi tercih etmektedirler.

Benzer bir evrim işletmeler tarafında da yaşanmaktadır. Dijital teknolojiler firmalar açısından etkinlik ve verimlilik artışı ile maliyetleri düşürme ve müşterilerine yeni değerler sunarak gelirlerini arttırma imkanı sunmaktadır. Firmaların dönüşüm süreçlerini başarı ile tamamlamaları çeşitli zorlukları barındırmakla birlikte yeni dönemde ancak kendi evrimlerini tamamlamayı başaran firmaların var olabileceği muhakkaktır.

Dijital teknolojiler gazete ve okurlar arasındaki ilişkiyi de temelinden değiştirmektedir. Okuyucular haber içeriğine zaman, mekan ve platform bağımsız ulaşmayı tercih etmektedirler. Kısa bir süre öncesine kadar gazete okumak isteyen bireyler kağıt olarak adlandırdığımız mecrayı ve üzerine mürekkep ile basılmış içeriği birlikte almak zorunda iken teknolojik kabiliyetler bu kısıtlamaları ortadan kaldırmış ve temelde erişim ekonomisini yaratmıştır. Bireyler mecra olarak kağıt yerine mobil cihazlara, bilgisayarlara veya tablet benzeri donanımlara yatırım yaparak internet bağlantısı ve abonelikler ile içeriğe ulaşma hakkını satın almaktadırlar. İçeriğin basılı olduğu mecra gereksiz konuma gelmiş ve içeriğin kendisi hak ettiği değere ulaşmıştır. Her ne kadar makale yazılı basın üzerine odaklanıyor olsa da gerek müzik endüstrisi gerekse film endüstrisindeki gelişmelere paralel kağıt da CD, DVD veya Video Kasetler gibi ömrünü tamamlayarak tarihe karışmaktadır.

Ülkemiz özelinde internet kullanıcı sayıları ve geniş bant erişim oranları global istatistiklere benzer seyretmektedir. 2008 yilında 6 milyon olan genişbant internet abone sayısının Haziran 2019 yılı itibarı ile 75,3 milyona ulaştığı görülmektedir. 4.5G teknolojisinin kullanıma sunulması ile birlikte Genişbant İnternet Abone Sayısında ciddi bir artış olmuş ve bireylerin dijitalleşme süreci ivme kazanmıştır (Figür3). 
Figür3: Genişbant İnternet Abone Sayıs1

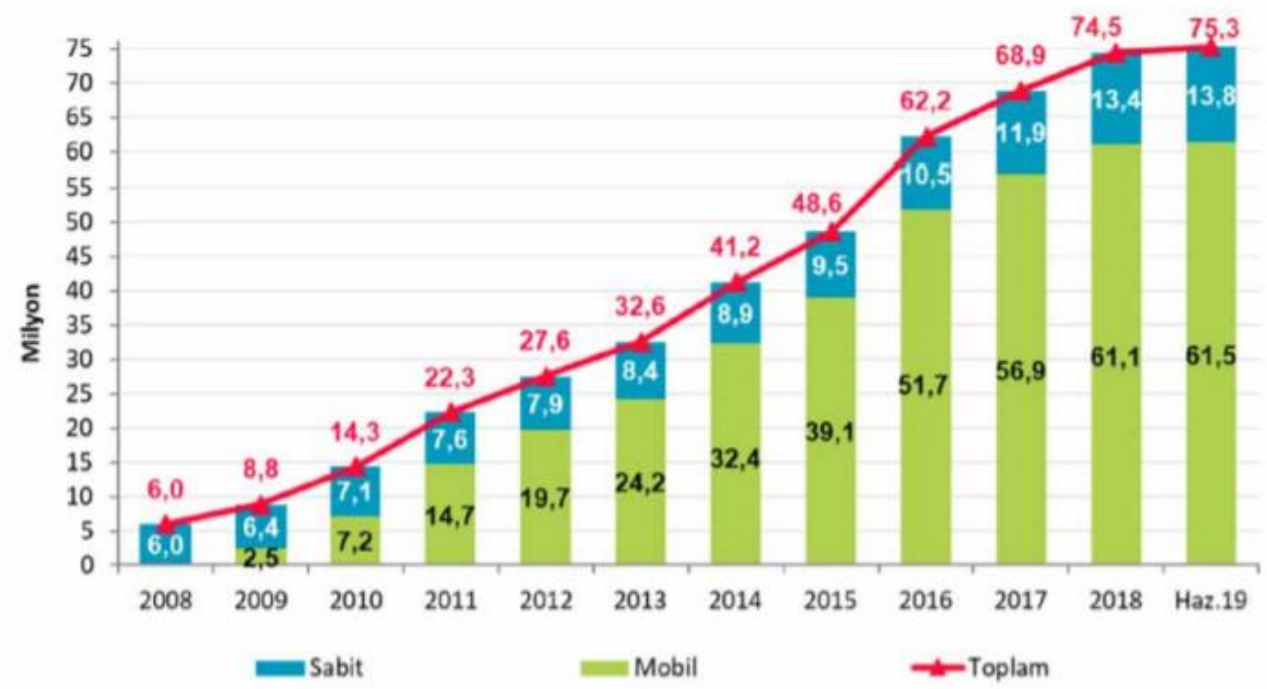

Kaynak:BTK Türkiye Elektronik Haberleşme Sektörü - Üç Aylık Pazar Verileri Raporu 2019 2. Çeyrek

Mobil cihazların kullanım oranlarına bakıldığında ülkemiz için bireylerde (0-9 yaş hariç) mobil penetrasyon oranının \%113,7 olarak gerçekleştiği görülmektedir. Bu derece yüksek oran ülkemizde tüm bireylerin mobil cihaz teknolojilerine sahip olduğuna hatta birden çok mobil aboneliğe sahip olarak farklı cihazlar ve platformlar kullandıklarına işaret etmektedir.

Figür 4: Mobil Abone Sayıs1

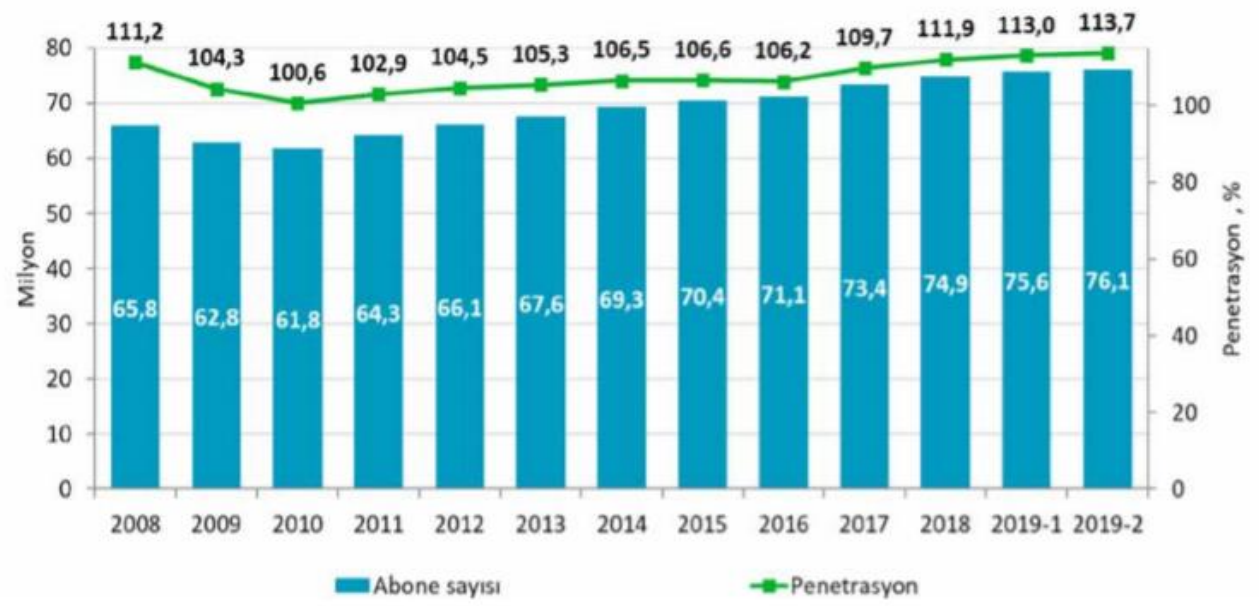

Kaynak:BTK Türkiye Elektronik Haberleşme Sektörü - Üç Aylık Pazar Verileri Raporu 2019 2. Çeyrek

Yeni dönemin teknolojileri, özellikle internet ve mobilite yeni medyanın ortaya çıkışını sağlamakla kalmamış, habercilik faaliyetlerine dijital kanallar üzerinden erişim ve yeni iş modelleri açısından oyun kurallarını belirlemektedir. 
"İnternet kısa sürede medya ortamını ve iletişim pratiklerini etkilemiş ve geleneksel gazetecilik ortamı yavaş yavaş internet gazeteciliğine evrilmiştir. Geleneksel medya gazeteciliğine göre; daha hızlı ve pratik olması, kullanıcı yani okuyucuyu interaktif pozisyona getirmesi ve zaman ve mekândan sınırsız olması nitelikleriyle internet gazeteciliği tercih sebebi olmaktadır. İnternet gazeteciliği ile geleneksel gazetecilik; kurum yapıları, pazara giriş olanakları, haber üretim yapıları ve etkileşim alanlarında da birbirinden farklılık göstermektedir. Yeni medya, geleneksel medyadan farklı olarak enformasyonun geniş kitlesel paylaşımına firsat tanımaktadır. Özellikle okurun, tepkisini aracısız bir biçimde anında verebilme imkânına sahip olarak haber yapım sürecine de doğrudan etki etmesi internet gazeteciliğinin önemini artırmaktadır. Ayrıca yeni medyanın göreceli olmakla birlikte geleneksel medyaya nazaran daha masrafsız ve daha geniş bir hedef kitleye sahip olduğu görülmektedir.” (Geray, 2003: 17- 19).

Yeni medya, internet ağları yardımıyla oluşturulan yeni nesil medya düzenidir. Geleneksel medyanın aksine yeni medyanın yayın organları tümüyle dijital donanımlar ve ortamlardan oluşmaktadır. Dijital aygıtlar üzerinden sunum yapılan tüm içerikler yeni medyanın alanı içerisinde tutulabilir. Örneğin twitter, Whatsapp mesajları, SMS, bloglar, web siteleri, video oyunları, video bazlı içeriklerin tümü yeni medyanın birer kanalı kabul edilmektedir.

"İnternet günlükleri bloglar, sadece bağımsız bireylerin çabalarıyla değil, büyük-küçük neredeyse tüm gazetelerin desteklediği yeni bir gazetecilik deneyimi olarak gazetelerin gelişimine ve içeriğine katkıda bulunmaktadır. 'Blog' kavramı yenidir ve henüz gazetecilik pratiği içindeki yeri netleşmemiştir, çünkü gelişme aşamasındadır... Ancak zaman içinde blogların da, onu doğru kullanan ve değerlendirenlerle birlikte, gazetecilik pratiğine önemli bir açılım ve kazanım getirmeleri beklenmelidir.

Yeni teknolojilerin gazetecilik pratiğine bir başka olumlu etkisi de 'yurttaş gazeteciliği' olmuştur. Mobil teknolojilerin gelişmesi ve yaygınlaşması, kullanıcılara sunulan mobil telefonların, fotoğraf ve video çekebilme özelliği sayesinde, dünyanın birçok yerindeki gelişme, haber değeri olsun-olmasın, sıradan insanlar tarafından görüntülenebilmektedir. Bu görüntüleri hızlı bir şekilde aktarmak çok kolaylaşmıştır. Medya kuruluşları da bunu değerlendirmektedir. Büyük haber ajansları ve basın-yayın kuruluşları haberlerinde, sıradan insanlardan gelen bu iletileri kullanarak 'yurttaş gazeteciliği'nin getirdiği kazanımları gazetecilik pratiği içinde değerlendirmeye başlamışlardır. Örneğin, 2004 Temmuz ayında, Londra Metrosu'ndaki bombalama eylemlerinde ilk görüntüler, sıradan insanların cep telefonlarıyla çektikleri görüntülerdi. Dünyanın en büyük haber ajansları müşterileri olan medya kuruluşlarına, artık cep telefonu ile çektikleri haber görüntüleri yollamakta, insanlar da gazete, dergi, televizyon veya internette cep telefonu ile çekilmiş olan bu haber görüntülerini izlemektedir. Bütün bunlar gazetelere ve gazetecilere içerik sağlamada önemli katkılar sağlamaktadır." (Özçağlayan, 2008: 156)

Türkiye'de teknolojik gelişmelerin yazılı basın üzerindeki etkileri tarihsel perspektiften incelendiğinde iki dönemin öne çıktığı görülmektedir. 1995 ve 2000 yılları arasındaki birinci dönemde internet henüz hayatımıza yeni girmiş ve bireyler arasında kullanımı yavaş yavaş yaygınlaşmaktadır (Gürcan, 2005: 41). Bu dönemde gerek okuyucular gerekse gazeteler internetin getirdiği faydalardan kısmen yararlanmaktadırlar. Gazeteler fiziki mecralar (kağıt) üzerinden yayınladıkları içerikleri internet üzerindeki sitelerine koymakta ve içeriğe farklı kanallardan erişim sağlamaya çalışmaktadırlar. Henüz içeriği zenginleştirmek veya dijital kanalların gereksinimlerine uygun içerik üretmek konusunda kaygıları bulunmamaktadır. Haber sitelerinde yayınlanan içerikler basılı gazetelerin sanal ortamlardaki bir kopyası olarak konumlanmaktadır.

2000 yılına gelindiğinde ise dijital kanallar üzerinden haberciliğin gerçek anlamda başladığını söyleyebiliriz. Bu dönemde başlayan ekonomik kriz seebi ile farklı pozisyonlarda çalışan yaklaşık 4000 medya sektörü temsilcisi işini kaybetmiştir. Mesleği gazetecilik olan bu

\section{Turkish Studies}

Volume 14 Issue 7, 2019 
kişilerden bir kısmı kısıtlı imkanları ile kendilerine iş alanı yaratmak ve mesleklerine devam etmek amacı ile girişimlerde bulunmuşlar ve internet siteleri açmışlardır. (Gürcan, 2005: 41).

$\mathrm{Bu}$ dönemde internet üzerinden yayın yapan haber portallarının faaliyete geçmeye başlamıştır. Medya sektöründe yakınsama olarak adlandırabileceğimiz gelişmelerin kendini hissettirdiği başlangıç noktası haber içeriklerinin zaman, mekan ve platform bağımsız olarak asıl işi habercilik olmayan dijital kanallar üzerinden yayılmaya başlamasıdır. Arama motorları dahil, bir çok irili ufaklı internet siteleri de haber kanalları oluşturarak günün gelişen haberlerini okuyucuya sunmaya başlamışlardır.

Akıllı cihazlar ve dijital teknolojilerin penetrasyonunun artması ile birlikte soyal medya kullanımı da hızla günlük hayatın merkezine yerleşmiş ve içerik paylaşımına yönelik güçlü bir mecra olmuştur. Gelişmeleri takip eden ve fursatı göre uluslararası medya kuruluşları sahip oldukları içeriği dünyanın her bölgesindeki kitleler ile dijital kanallar üzerinden dağıtmaya başlamışlardır. Sosyal medya içerik üretimi ve içerik tüketimi süreçlerini de derinden etkilemiştir; bu döneme kadar sadece sunulan içeriği tüketen bireyler artık kendi içeriklerini oluşturarak Twitter, Facebook gibi sosyal medya araçları üzerinden etkileşimde bulundukları kitleler ile paylaşmaya ve basılı gazeteler için 'haber kaynağı' olmaya başlamışlardır (Cebeci, 2018).

Figür 5: İçeriğin Dijital Kanallara Evrilmesi

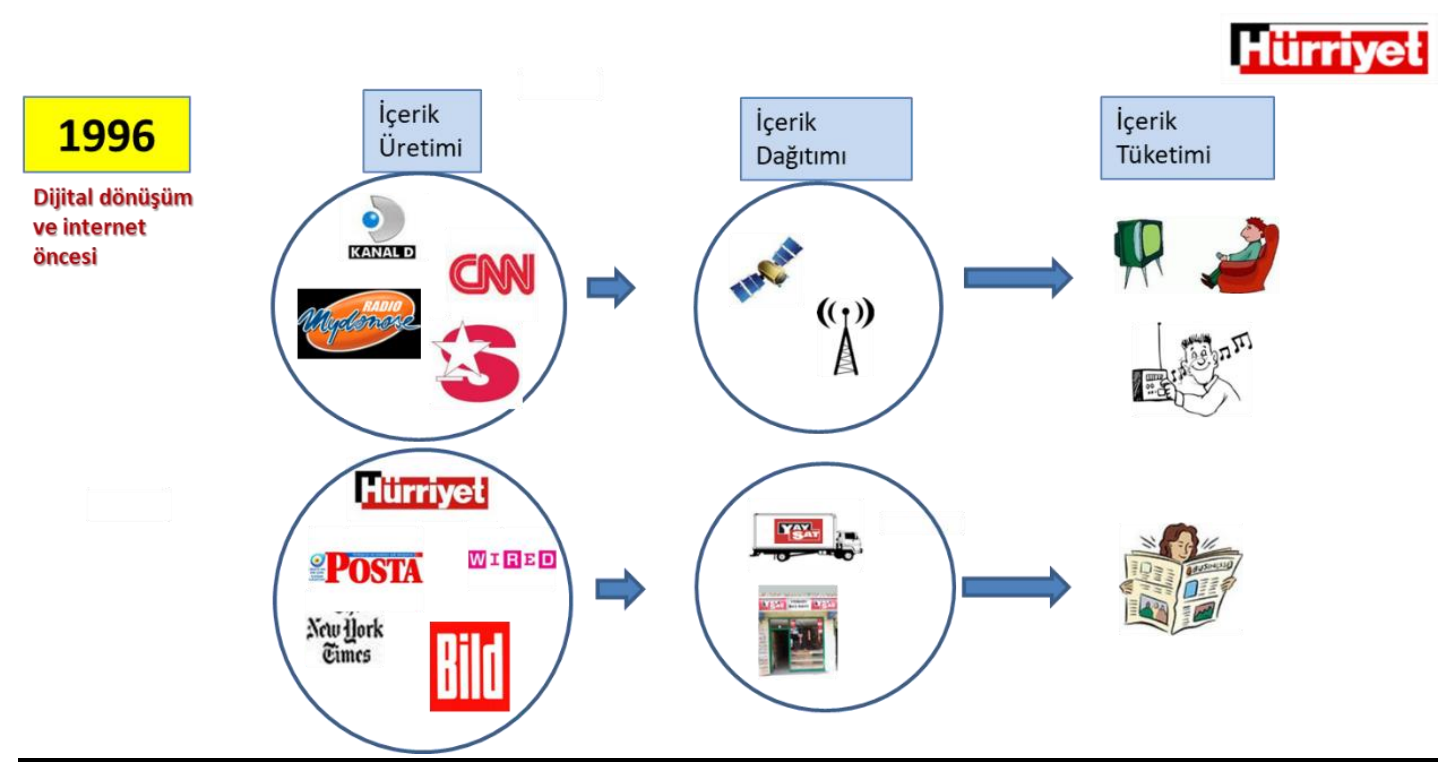




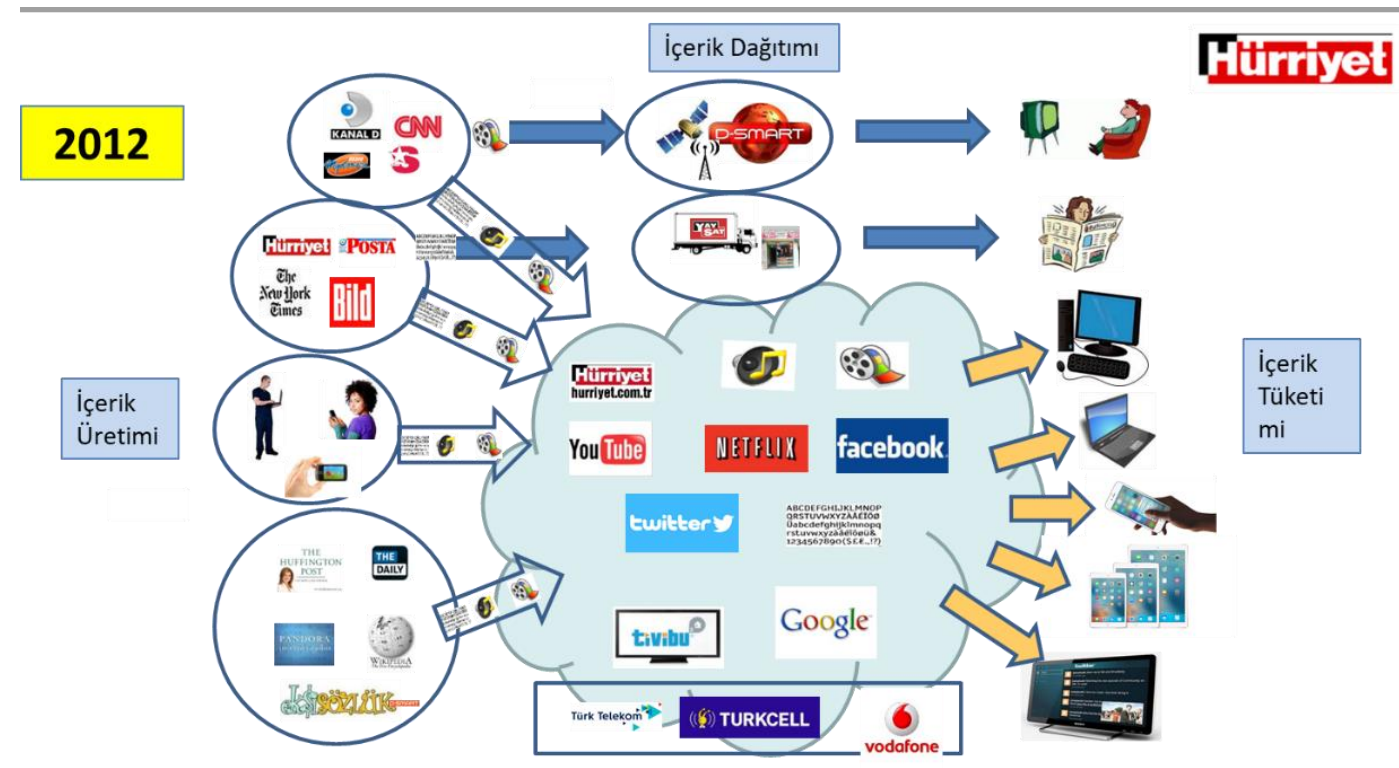

Kaynak:Hürriyet’te Mobil Dönüşüm Sunumu (Gülcan, 2016)

Medya sektöründe yakınsama; içerik üretimi, içerik dağıtımı ve içerik tüketimi boyutlarının iç içe geçerek tüm elementlerin etkileşim halinde olduğu karışık ve dinamik yeni dönemi işaret etmektedir. İçerik gerek ticari amaçları olan işletmeler gerekse paylaşım motivasyonu olan bireyler tarafindan aynı anda üretilmekte ve karşılıklı tüketilmektedir. Dijital olarak formatlanan içerik yayıldığı kanalara bağlı olarak geçmişteki zorunlu yapılarını kırarak (basılı metin, radyo frekansı veya televizyon görüntüsü) bulunduğu iletişim kanalının formatına bağlı olarak kısa metin (SMS), uzun metin (dijital gazete), ses, resim, poster, video ve daha birçok farklı türde tüketim için dağılmaktadır (Figür5).

Yönetiminde bulundukları medya kurumunun Dijital Dönüşüm'üne liderlik eden profesyoneller dijital teknolojileri iyi anlamalı, özümsemeleri ve kendi iç süreçlerine başarı ile yansıtarak ürettikleri yeni değerler ile geleceği hazırlamalıdırlar. $\mathrm{Bu}$ sebeple yeni medya ve geleneksel medya arasındaki farkın net olarak ortaya konması büyük önem taşımaktadır (Figür6)

Figür 6: Yeni Medya ve Geleneksel Medya Karşılaştırması

\begin{tabular}{|l|c|c|}
\hline & Geleneksel Medya & Yeni Medya \\
\hline Kanal & Az sayıda & Çok sayıda \\
Kontrol & Gönderen & Alıcı \\
İletim & Tek yönlü & İki yönlü, etkileşimli \\
İçerik & Sınırlı & Çeşitlendirilmiş \\
Kapsama Alanı & Bölgesel, küresel & Küresel \\
Toplumsal Kontrol & Kanunlar, meslek ve ahlâk & Teknik aygıtlar, izleme \\
Zaman & ilkeleri, halk eğitimi & Asenkron \\
Yapısı & Senkron & Merkeziyetçi olmayan \\
& Merkeziyetçi & (çok noktadan-çok noktaya) \\
\hline
\end{tabular}

Kaynak: Celalettin Aktaş, (2007). Yeni Medyanın Geleneksel Medya İleKarşılaştırılması. Medya Üzerine Çalışmalar, İstanbul: Beta BasımYayım Dağıtım, 107-120. 
20. yüzyıl sonlarına kadar içeriğin sınırlı kaynaklardan dağıtılan içerik bugün dijital platformlar üzerinde sayısız formata girebilmektedir. Geçmişte sınırlı sayıda üretici tarafindan üretilen içerik rahatlıkla kontrol edilebilirken bugün milyarlarca birey içerik üretme ve çevresine sosyal medya üzerinden yayma imkanına kavuştuğu için hızla yayılan içeriği kontrol etmek ve hatta bazı durumlarda kaynağını bulmak dahi zorlaşmıştır. İçerik üretimindeki bireylerin katkısı çeşitliliği getirmiş ve içeriklerin derinliği artmıştır. Bir merkezden tek taraflı yayılan içerik yerine üreten ve tüketen tarafların birlikte etkileşime girerek içeriği karşılıklı oluşturdukları yeni düzene geçilmiştir. Dağıtım kanallarındaki kısıtlar nedeni ile üretildiği lokasyonda tüketilen içerik sınırları aşmış ve saniyeler içerinde dünyanın tüm noktalarına ulaştırılabilir olmuştur. Dijital platformlar ile birlikte içeriğin tüketiminde zaman anlayışı da değişmiş bireylerin talebine göre istenildiği an tüketilebilir yapıya kavuşmuştur.

Akıllı telefon ve tabletlerin hızla ucuzluyor olması ve kullanıcı sayısının 1 milyar kişiye ulaşması dijital medyayı daha cazip kılmaktadır. Yeni medya döneminde ise araştırmacı gazetecilik geri dönmektedir. Rutin gelişmelere, demeçlere duygusal ve kendi tarafindan bakarak köşe yazısı yazanların da mesleki saygınlıkları ile okunurluk oranları da azalmaktadır. Yeni dünyanın okuyucusu ve izleyicisi yönlendirilmek istememektedir. (Soysal, 2018: 3)

\section{Habercilik Endüstrisinde Yeni Ticari Modeller}

"Ayakta kalabilmek için büyüme, büyümek için tiraj artırmak, tirajı arttırmak için de rekabet etmek zorunda olan gazeteler, fiyat ve dağıtım dışında kalan unsurlarla da rekabet etmek zorundadırlar ki bu rekabette kendisi için tutundurma faaliyetleri büyük önem taşımaktadır. Yazılı basının ekonomik yapısını etkileyen bir diğer önemli faktör de fiyat artışlarıdır. Mecranın ürününde yapılan fiyat artışları kısa vadede pazar payının artması veya azalmasında etkili olmaz ama tirajın düşüşünde en büyük etkenlerden biridir. Fiyat artışlarını etkileyen faktörler arasında kağıt, boya, elektrik, haberleşme maliyetleri, personel giderleri gibi maliyet artış faktörleri ön plandadır." (Kuyucu, 2012: 28)

Okur tercihlerindeki değişim gazetelerin gelir kaynaklarının düşmesinin ana nedeni olarak ortaya çıkmaktadır. Gazete ve dergi tirajlarının yıllar içerisinde sürekli düşmesi gazete satış gelirlerinin yok olması sonucunu doğurmaktadır. "Gazetelerin yayın hayatlarını devam ettirebilmesinde, ilan ve reklam gelirlerinin satışlardan elde edilenden daha büyük ve önemli olduğu herkes tarafindan bilinmektedir...Türkiye'de reklam ve ilanların dağıtımı, hem siyasal iktidarlar hem de reklamı yapan ve yayınlayanların kendi politik ve ekonomik çıkarları için çatışığı alanlardan biri olagelmiştir. Siyasal iktidarlar için reklam ve ilanların denetimi, iktidarlarının yeniden üretilmesi ve pekiştirilmesi kanallarının sağlanabilmesi açısından önemli bir mücadele alanıdır. Gazete sahipleri için gazetelerin niteliksel ve niceliksel gelişiminde ilanlar, en önemli finansal kaynakların başında gelmektedir.” (Kızılca, 2017: 589, 592)

Gazetelerin temel gelir kaynağı olan reklam gelirleri de yıllar içerisinde tüketici tercihlerinin değişimiyle birlikte gerilemeye başlamıştır. Figür 7 Reklamcılar Derneği tarafından açıklanan Türkiye Medya Harcamaları raporunun konsolide edilmişs sayılarını 2012 ve 2018 yılları için göstermektedir.

2011 yılında Türkiye medya harcamaları içerisinde \%22,4 paya sahip olan basın 2018 yılına gelindiğinde yalnızca \%9.4 pay kapabilmiştir. Yıllar içerisinde gelirlerdeki nominal değişim incelendiğinde ortaya çıkan tablo basın sektöründe çalışan işletmeler açısından daha vahim sonuçlar ortaya koymaktadır. Yıllık ortalama enflasyon seviyesinde dahi gelirlerini arttıramayan basın 2011 ve 2018 yılları arasında \%25,5 gelir kaybetmiştir. Eğer hesap enflasyon etkisini de düşünerek reel sayılar ile yapılır ise reklam gelir kaybının ne kadar büyük olacağı görülmektedir. $\mathrm{Bu}$ tablo yazılı basının ticari açıdan sürdürülebilirlik riski taşıdığını net şekilde ortaya koymaktadır. 
Oysa aynı dönem içerisinde Türkiye medya harcamaları \%76,4 seviyesinde artmıştır. Tüm mecralar içerisinde de yıldızı parlayan mecranın dijital olduğu açık şekilde görülmektedir. 2011 yılında yalnızca \%15 paya sahip olan dijital mecralar 2018 yılına gelindiğinde $\% 28,9$ oranına çıkarak reklam pastasından aldığı payı iki katına çıkartmıştır.

Figür 7: Türkiye Medya Harcamaları (Milyon ")

\begin{tabular}{|c|c|c|c|c|c|c|c|c|}
\hline & 2011 & 2012 & 2013 & 2014 & 2015 & 2016 & 2017 & 2018 \\
\hline TV & 2,448 & 2,606 & 2,908 & 3,052 & 3,270 & 3,680 & 3,834 & 3,875 \\
\hline Dijital & 702 & 918 & 1,140 & 1,377 & 1,646 & 1,872 & 2,078 & 2,385 \\
\hline Basın & 1,048 & 1,114 & 1,139 & 1,119 & 1,095 & 1,069 & 963 & 780 \\
\hline AçıkHava & 306 & 532 & 595 & 663 & 697 & 712 & 805 & 852 \\
\hline Radyo & 121 & 130 & 133 & 136 & 139 & 169 & 255 & 269 \\
\hline Sinema & 53 & 54 & 57 & 62 & 71 & 81 & 85 & 89 \\
\hline Toplam & 4,678 & 5,353 & 5,973 & 6,409 & 6,918 & 7,583 & 8,020 & 8,252 \\
\hline
\end{tabular}

Kaynak: Reklamcılar Derneği

Pazarın gerçekleri de sayılarla göstermektedir ki habercilik işi ile uğraşan ve içerik üreten ticari işletmeler maliyetlerini karşılayabilmek ve karlılıklarını koruyarak kurumsal sürdürülebilirliklerini sağlayabilmek için dijital kanallara uygun operasyonel faaliyetlerde bulunmak zorundadırlar.

Gazetecilik faaliyetlerini dijital kanallar üzerine taşıma kabiliyetine sahip kuruluşlar; düşen maliyetler ve yeni gelir firsatları ile esnek, karlı ve sürdürülebilir ticari modeller geliştirebilmektedirler. (Saka,2017). Saka, gazetecilik için dijital dönüşümle birlikte ortaya çıkan ya da denemeleri yapılan yeni gelir ve iş modellerini MarcAndreessen medya sektöründeki çalışmalarına dayandırarak özetlemiştir.

Bahsi geçen gelir modelleri incelendiğinde yazılı basının yeni döneme uyum sağlama ve yeni iş modelleri keşfetme sürecinde ortaya üç farklı gelir kaynağının çıkmakta olduğu bugün için gözükmektedir.

İlk başlık altında değerlendirebileceğimiz reklam, abonelikler ve paralı içerik gelir modelleri geleneksel iş faaliyetlerinin dijital kanallara kayması ile birlikte dijital dönüşümünü sağlamış olan kurumların gelirlerini güvence altına alarak faaliyetlerine devam etmeleri prensibine dayanmaktadır. Buna karşın sektörde yapılan yorumlar her ne kadar habercilik faaliyetlerine duyulan ihtiyacın devam etmekle birlikte oldukça uzun zamandır ana kaynak olan bu gelir modellerinin artık sonuna geldiği ve yeni iş modellerine ihtiyaç duyulduğu yönündedir. Yeni iş modellerine duyulan ihtiyaçla birlikte habercilik alanında çalışan kurumlar da kendi faaliyetleri esnasında geliştirdikleri ve sahip oldukları değerleri kullanarak yeni ürün ve hizmetler üretmeye odaklanmışlar ve bugüne kadar gündemde olmayan alanlarda da çalışmaya başlamışlardır. Konferans ve etkinlik organizasyonları ile çapraz medya satışları yeni dönemde karşılaşılan yeni değer önerileri olarak isimlendirilebilir. Medya endüstrisinde çalışan şirketler doğal olarak kurum ve bireyler bazında güvenilir markaları ile geniş kitlelere ulaşabilmekte ve habercilik dışındaki içerikleri de işleyerek satılabilir formatta pazara sunabilmektedirler.

Piyasada var olabilmek için medya kuruluşları farklı gelir kaynaklarının karışımından oluşan yeni ticari modeller geliştirmelidir. Örneğin gelirinin bir bölümünü reklamlardan, bir bölümünü bağışlardan, birazını sponsorlardan ve birazını da kamu kaynaklarından karşılayabilir. 
Yakın süreçte TheGuardian, okurlarının düzenli olarak kendilerine bağış yapmalarını sağlamıştır. Teknoloji firmalarına veya akıllı telefonlar gibi teknolojik cihazlara uygulanacak vergiler üzerinden de gazeteciliğin finansmanı sağlanabilir. (Akçura, 2019: 6)

"Haber siteleri, çoğu zaman abone oldukları ajanslardan fotoğraf sağlamaktadırlar ya da çeșitli internet kaynaklarından izinli/izinsiz aldıkları fotoğrafları kullanmaktadırlar. Yine haberler çoğunlukla ajanslardan hazır olarak geldiği için üzerinde herhangi bir editasyona gerek duyulmamaktadır. Dolayısıyla haber sitelerinin haber üretim maliyetleri son derece düşüktür. Muhabir, foto-muhabiri, köşe yazarı istihdam edilmediğinden içerik oluşturmaktaki maliyeti artırıcı unsurlar ortadan kalkmaktadır... Yeni iletişim teknolojileri ve internetin gazetecilik alanında kullanılmaya başlamasıyla birlikte gazeteciliğin dönüşümü gerçekleşmiştir. Günümüzde gazeteciliğin istihdamı, çalışma koşulları ve biçimleri pazar yapısının taleplerine göre biçimlenmektedir. Dolayısıyla yeni medya sektöründeki gelişmeler bu alandaki istihdam açısından da önemlidir. Örneğin yeni medyanın gelişimi ile web sayfa tasarımcılarına, dijital tasarımcılara daha fazla gereksinim duyulmaktadır." (Büyükbaykal, 2018: 59)

Habercilik ihtiyacı ve bu ihtiyacı karşılamaya yönelik faaliyetler gelecekte de var olmaya devam edecektir, buna karşın içeriğin bireyler ile buluşturulmasında yeni dönemin imkanlarını ve tercihlerini göz önünde bulundurarak kendilerini adapte edebilen yazılı basin temsilcileri yaşamlarını sürdürebilecektir.

\section{Küresel Ekonomide Yavaşlama ve Yazılı Basına Finansal Yansıması}

2019 yılı içerisinde küresel ekonomide genel bir yavaşlama eğilimi güçlenmekte, ticaret savaşları gündemi belirlemekte ve jeopolitik risklerde artış görülmektedir. Artan risklerle birlikte gelişmekte olan piyasalardan gelişmiş piyasalara yönelik artan sermaye hareketleri Türkiye pazarını da etkilemekte ve işletmeler finansal konuları yönetmek amacı ile daha fazla zaman harcamaktadirlar.

Ekonomik İşbirliği ve Kalkınma Örgütü (OECD) raporunda yer alan sayılar küresel ekonominin içinde bulunduğu durum ve gidişatıyla ilgili genel resmi ortaya koymaktadır. 2018 yılı içerisinde yapılmış olan 2019 yılı için \%3,5 büyüme oranı son revizeler ile birlikte \%3,2'ye çekilmiştir. Büyüme hızı oranının düşürülmesinin arkasında yatan sebep olarak artan küresel ticari gerilimlerin etkili olduğu belirtilirken, ticaret ve yatırımların özellikle Avrupa ve Çin'de sert bir şekilde düştüğü, iş ve tüketici güvenindeki düşüşle politikaların belirsizliğini koruduğu vurgulanmaktadır.

Genele bakıldığında ticari gerilimlerin etkisiyle küresel ekonominin 2019'da \%3,2, 2020 'de de \% 3,4 büyüyeceği tahmin edilirken, söz konusu büyüme oranlarının son 10 yılın en düşük düzeylerinde olduğu dikkat çekmektedir. Her ne kadar farklı ekonomiler para politikalarını revize ederek önlem almaya başlamışlarsa da küresel ortamdaki olumsuz riskler varlı̆̆ını sürdürmektedir ve verileri yorumlayan OECD Baş Ekonomisti LaurenceBoone, OECD raporlarında ifade edilen ticari ve politik belirsizliklerin dünya ekonomisine zarar verebileceği ve insanlar arasında büyüyen fikir ayrılığını artırabileceği uyarısını yapmaktadır.

Önümüzdeki dönemde finansal ekonomiler üzerinde baskı yapan faktörler aşağıdaki başlıklar altında toplanmaktadır:

- $\quad \mathrm{ABD}$ ve Çin arasında ek gümrük vergileri nedeniyle olası ticaret savaşının sürmesi

- $\quad \mathrm{ABD}$ ve Avrupa Birliği’nin yeni ek gümrük vergileri uygulamaları

- Ortadoğu'da yükselen tansiyon ve enerji kaynaklarının fiyatlaması üzerinden

yarattığı baskı 


\begin{tabular}{cc}
\hline • Çin ekonomisindeki sert düşüşün engellenmesi için yürütülen politikaların yetersiz \\
•lması & Brexit süreci de dahil olmak üzere Avrupa'daki politika belirsizliğinin büyümeyi \\
kısıtlamasi &
\end{tabular}

- $\quad$ Yüksek borç ve kötü kredi kalitesinin oluşturabileceği finansal zayıflıklar

OECD raporu; belirtilen küresel risklere karşı alınması gereken ekonomik tedbirlerle ilgili görüş ve önerilerini detaylı şekilde paylaşmakla birlikte "Dijitalleşme" altında özel bir bölüm ayırarak alışılmış rapor formatının dışına çıkmakta ve küresel büyüme oranlarında dijital dönüşümün önemine dikkat çekerek bu alanda yapılması gerekenlerle ilgili yorumları paylaşmaktadır.

Özetle dijital dönüşüm firmaların ürün ve hizmet üretim süreçlerini değiştirmekte, etkinlik ve verimliliklerini arttırmakta, inovasyon ile birlikte yeni değerler ortaya çıkarmalarına imkan sağlamaktadır. Bununla birlikte dijital dönüşümün sağladığı imkanlardan faydalanabilmek için yapısal reformların devreye alınması gerekliliği aşikardır çünkü bugüne kadar elde edilen sonuçlar kısıtlı olmuş ve ekonomik büyümeye beklenen ivmeyi henüz sağlayamamıştır.

Hükümetlere düşen görev dijital dönüşümün etkin şekilde hayata geçmesini sağlamak amacı ile ilgili politikaları oluşturmak ve desteği sağlamaktır. Firmalar tarafinda ise teknolojilerin anlaşılması ve üretim süreçlerine uygulanması için gerekli stratejilerin belirlenerek hızla hayata geçirilmesidir. Bu sürecin zaman ve efor gerektirdiği bilinmekle birlikte üzerinde çalışılmasına ihtiyaç duyulan reformlar; işgücü yetkinliğini arttırılması, dijital dönüşüm için firmaların ihtiyaç duydukları yatırım fonlarına erişimin sağlanması, Araştırma ve Geliştirme (ArGe) faaliyetlerinin desteklenmesi ve yeni dönemin ihtiyaçlarına paralel yasal düzenlemelerin devreye alınması olarak hükümetlerin önünde beklemektedir.

Küresel ekonomik gelişme ve risklere bağlı olarak gerek artan maliyetler gerekse düşen gelir nedeni ile yazılı basının da süreçten olumsuz etkilendiği bilinmektedir. Yazılı basının temel hammadde girdileri kâğıt ve mürekkep giderleri son dönemde oldukça yükselmiştir. Baskı sürecine yönelik yeni yatırımların yapılması ve makine parkurunun bakımının yapılması yüksek finansal maliyetler nedeni ile işletmeleri oldukça zorlamaktadır. Emek yoğun operasyonların yüksek olduğu yazılı basın endüstrisi personel ve dağıtım maliyet kalemlerindeki artan maliyetleri karşılamakta da zorluk çekmektedir.

OECD raporunda belirtildiği şekilde yazılı basın açısından küresel ekonomide yaşanan risklere karşı öncelikle ele alınması gereken önlemin dijital dönüşüm süreçlerinin devreye sokulması; etkinlik ve verimlilik artışının sağlanarak ticari açıdan yazılı basın endüstri üzerindeki maliyet risklerinin yönetilmesi büyük önem taşımaktadır.

Değişimin önemli parametrelerinden bir tanesi olan Küresel Ekonomik Koşullar yazılı basın açısından da yeni zorlukları ve konuları gündeme getirmekte gerek kamu gerekse şirket yönetimlerin herkes için faydalı ve sürdürülebilir bir ekonomik büyüme konusunda birlikte çalışmalarını zorunlu kılmaktadır.

\section{Sonuç}

Küresel ekonomik gelişme ve risklere bağlı olarak gerek artan maliyetler gerekse düşen gelir nedeni ile yazılı basının da süreçten olumsuz etkilendiği bilinmektedir. Yazılı basının temel hammadde girdileri kâğıt ve mürekkep giderleri son dönemde oldukça yükselmiştir. Baskı sürecine yönelik yeni yatırımların yapılması ve makine parkurunun bakımının yapılması yüksek finansal maliyetler nedeni ile işletmeleri oldukça zorlamaktadır. Emek yoğun operasyonların yüksek olduğu yazılı basın endüstrisi personel ve dağıtım maliyet kalemlerindeki artan maliyetleri karşılamakta da 
zorluk çekmektedir. OECD raporunda belirtildiği şekilde yazılı basın açısından küresel ekonomide yaşanan risklere karşı öncelikle ele alınması gereken önlemin dijital dönüşüm süreçlerinin devreye sokulması; etkinlik ve verimlilik artışının sağlanarak ticari açıdan yazılı basın endüstri üzerindeki maliyet risklerinin yönetilmesi büyük önem taşımaktadır. Değişimin önemli parametrelerinden bir tanesi olan Küresel Ekonomik Koşullar yazılı basın açısından da yeni zorlukları ve konuları gündeme getirmekte gerek kamu gerekse şirket yönetimlerin herkes için faydalı ve sürdürülebilir bir ekonomik büyüme konusunda birlikte çalışmalarını zorunlu kılmaktadır.

Haberlerin internet ortamından ulaş1labilir hale gelmesiyle birlikte geleneksel gazeteciliğin yapısında değişimler meydana gelmiştir. Dijital yayıncılık dünya genelinde hızla yaygınlaşmaktadır. İnternet ortamı gazetecilik mesleğinde de birtakım dönüşümleri beraberinde getirmiştir. İnternet gazeteciliğinde hızlı erişim vardır. Habercilikte zamana karşı verilen yarışta sağlanan üstünlük çok önemlidir. İnternet ortamında basılı gazeteye göre çok daha ucuz ve hızlı bir şekilde habercilik yapılabilmektedir. Dağıtım için harcanan paradan ve zamandan da tasarruf söz konusudur. Yani giderler açısından diğer kitle iletişim araçlarına göre daha hesaplıdır. Yayın arşivine ulaşmak kolaydır. Tek bir merkezden yapılan internet gazeteciliğinin küresel bir dolaşımla sağlanacak erişilebilirliği, daha çok okuru da beraberinde getirecektir. Dolayısıyla bilgiye kolay ve hızlı erişim, internetin en önemli tercih sebebidir. Aynı zamanda internet sayesinde artık insanlar istedikleri haberleri seçerek kendi gazetelerini oluşturmaktadır. Günümüzde artık hızla gelişen teknoloji sayesinde ilgi duyduğumuz türde haberlerden oluşan yani kendimize özgü bir gazeteyi oluşturabilmemiz mümkündür.

İletişim ve bilişim sektöründeki hızlı gelişmelerin neticesinde yazılı basın dönüşüm sürecine hazırlıksız yakalanarak girmiştir. Farklı fırsatları barındıran yeni kabiliyetler, özellikle yerel tarafta yeterli bilgi, tecrübe ve finansal kaynaklara sahip olmayan yazılı basın için bir gelişim alanı olarak durmaktadır.

Süreç içerisinde yazılı basın yeni teknolojileri içselleştirerek ve operasyonel süreçlerine yansıtarak yeni iş modelleri, yeni kanallar, yeni formatlar ve yeni organizasyonel yapılar içerisinde geleceğe ilerlemek mecburiyetindedir. Dijital Dönüşüm gereksinimi zorlu ve uzun bir yolculuk olmakla birlikte içerisinden geçilen süreci tehdit olarak değil geleceğe sağlam adımlar ile ilerlemek için firsat olarak algılamak yazılı basın temsilcileri açısından doğru yaklaşım olacaktır. Yazılı basın sektörünün çağın koşullarına uyum sağlayacak şekilde yeni döneme hazır olmasının sağlanması gazetecilik faaliyetlerinin devamlılığı açısından büyük önem taşımaktadır.

\section{KAYNAKÇA}

Akçura, B. (2019). Gazetecilik Ölmüyor Dönüşüyor, Milliyet Gazetesi Pazar Eki, 28 Nisan 2019.

Aktaş, C. (2007). Yeni Medyanın Geleneksel Medya İleKarşılaştırılması. Medya Üzerine Çalışmalar, İstanbul: Beta BasımYayım Dağıtım, 107-120.

Bilgi ve İletişim Teknolojileri Kurumu (BTK). (2019). PazarVerileri Raporu, 2019 Y1lı 2. Çeyrek. https://www.btk.gov.tr/uploads/pages/pazar-verileri/2-ceyrekraporu-2019-kdisi.pdf

Büyükbaykal, C.I. (2018). Dijital Teknoloji ve Gazeteciliğin Dönüşümü, İletişim Çalışmaları 2018, Ed: Aydın Ziya Özgür, Aytekin İşman, Sakarya: 51-63.

Cansabuncu, İ. A. (2013). Türkiye'de Yeni Medya Yayıncılığı ve Yeni Medya Ürünlerinden Bir Örnek: Magazin Tablet Dergisi, Yayımlanmamış Yüksek Lisans Tezi, İstanbul Üniversitesi Sosyal Bilimler Enstitüsü.

Cebeci, M. (2018, 5 Ocak). Kağıt Baskıdan Dijital Serüvene.http://blog.milliyet.com.tr/kagitbaskidan-dijital-seruvene/Blog/?BlogNo=578725 
Çakır, H. (2007). Geleneksel Gazetecilik Karşısında İnternet Gazeteciliği, Erciyes Üniversitesi İletişim Fakültesi Dergisi, Sayı:22, Kayseri.

DistripressCirculationMonitor 2018

Ekonomik Kalkınma ve İşbirliği Örgütü (OECD) Ekonomik Görünüm Raporu. OECD Economic Outlook May 2019

Geray, H. (2003). İletişim ve Teknoloji Uluslararası Birikim Düzeninde Yeni Medya, Ankara: Ütopya Yayınları.

Gülcan, U. (2016). Hürriyet’te Mobil Dönüşüm Sunumu

Güngör, N.\&Tellan, T. (2017). Basında Tekelleşme ve Oligopolleşme, Türkiye'de Kitle İletişimi Dün-Bugün-Yarın, Ankara: Gazeteciler Cemiyeti, 456-468.

Gürcan, H. İ. (2005). İnternet Haberciliğinde Etik Değerler. İstanbul Üniversitesi İletişim Fakültesi Dergisi, Sayı:22, İstanbul, 39-46.

Kadıŏglu, Z. K. (2018). Türkiye'de Medya Sahipliği Ekseninde Mülkiyet Yapılarındaki Değişimin Kronolojik Analizi (1950-2010), İnsan\&İnsan Dergisi, Y11:5, say1:16, 100-119.

Kızılca, G.K. (2017). Resmi-Özel İlanlar ve Basın İlan Kurumu, Türkiye'de Kitle İletişimi DünBugün-Yarın, Ankara: Gazeteciler Cemiyeti, 579-592.

Kuyucu, M. (2012). Türkiye’de Medya Ekonomisi, İstanbul: Esen Kitap.

Mengü, M. (2003). Haber Diliyle Yapılandırılan Küresel Söylem: CNN Türk ve CNN International Örneği, Yayımlanmamış Doktora Tezi, İ.Ü. Sosyal Bilimler Enstitüsü, İstanbul.

Mora, N. (2002). Sözden İnternete Gazetecilik, İ.Ü.İletişim Fakültesi Dergisi, İstanbul: 105-121.

Önür, N. (1998). Medya ve Eğitim, Ankara: Atilla Yayıncılık.

Özçağlayan, M. (2008). Gazetelerin Gelişimi ve Gazeteciliğin Geleceği (Yeni Teknolojiler ve Medya Ekonomisi Açısından Genel Bir Değerlendirme), Marmara İletişim Dergisi, Say1:13, İstanbul: Doğa Sektörel Yayın Grubu, 131-160.

Saka, E. (2017). Dijital Dönüşüm ve Gazetecilik için Yeni İş Modelleri [DigitalTransformationand New Business ModelsforJournalism].

Soysal, M. (2018). Polemikten Kaçış Günleri, Milliyet Gazetesi, 20 Kasım 2018.

TÜİK veri derlemesi - https://dokuz8haber.net/manset/verilerle-yazili-basin-tirajlar-dusuyorgazeteler-kapaniyor-medya-cikis-yolu-ariyor/

Türkiye Sosyal-Siyasal Eğilimler Araştırması. (2019). Kadir Has Üniversitesi Türkiye Çalışmaları Merkezi.

(http://www.socialmediatr.com/13.12.2016)

Yangil, F. M. (2015). Kurumsal sürdürülebilirlik kapsamında sürdürülebilirlik raporlarına yönelik içerik analizi: Türkiye'deki en büyük 100 sanayi işletmesi. İşletme Araştırmaları Dergisi, 7(3), 356-376. 